\title{
How Debt Financing Decisions Relate With Financial Performance Of State-Owned Corporations In Kenya
}

Dr. Micah Odhiambo Nyamita, Durban University of Technology, South Africa Prof. Nirmala Dorasamy, Durban University of Technology, South Africa Dr. Hari Lall Garbharran, Durban University of Technology, South Africa

\begin{abstract}
Financing decisions, especially debt financing, have been revealed to have noteworthy implications for the operations of corporations. Studies on finance have revolved around the theory that certain financial policies, like debt financing, should either boost or hamper a corporation's competitive performance. The aim of this study, therefore, was to determine the effects of debt financing on the financial performance of state-owned corporations in Kenya. The "financial leverage", which is the proportion of debt financing of state-owned corporations, based on the total debt and the total assets, was the object of analysis for the period 2002 to 2012. The fixed effects (FE), random effects (RE) and the generalized method of moments (GMM) panel data regression analysis models were applied using the financial performance ratios, such as ROA, ROI and ROE. The results determined that debt financing is inversely related to financial performance of state-owned corporations in Kenya.
\end{abstract}

Keywords: Debt Financing; Financial Performance; Financial Leverage; Debt Financing Theories; State-Owned Corporations

\section{INTRODUCTION}

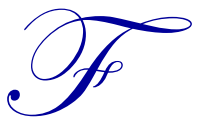

inancial capital is one of the mandatory resources needed for corporations to start and subsequently operate. Financing decisions, especially debt financing, have been revealed to have noteworthy implications for the operations of corporations, risk of failure, performance of corporation and the prospective of the corporation to expand (Cassar, 2004, p. 261). According to Goswami and Shrikhande (2001, p. 39), most corporations, looking for external financing options, mainly use debt financing rather than equity financing. They argued that this is the case for both local and transnational corporations across different developed economies of the world. Singh (1995, p. xi), using data from selected developing countries, found that firms in developing countries made significantly more use of debt finance to finance their growth than is typically the case in the developed countries. Rajan and Zingales (2012, p. 1421), in their study of private sector public corporations in major industrialised countries, concluded that, at an aggregate level, debt financing patterns are similar across the nations.

The information on the extent of debt financing within the state corporations is only available to government officials and, to a small extent, to the public through the legislative assemblies. Most of the reporting systems for the public sector in developing countries are still in the process of modernisation and this makes the availability of their financial information complicated. In recognition of this fact, studies on debt financing have been done mostly using data from developed economies with more private-sector corporations (Foster and Young 2013: 6). The study, therefore, attempted to fill the gap in the literature by using data from corporations within the public sector and from a developing economy, like Kenya. The study is part of a major project that investigated the factors influencing debt financing and its effects on financial performance for state corporations in Kenya. The subpart of the project that attempted to identify the major factors influencing debt financing, such as profitability, asset 
tangibility and corporation growth, within the state-owned corporations in Kenya has been published (Nyamita, Garbharran and Dorasamy 2014). Most of the state-owned corporations in Kenya have been identified for privatisation because of their poor financial management policies, including debt financing (Debrah \& Toroitich, 2005, p. 209). Hence, it is of interest to find out how debt financing practices, within the state-owned corporations, relate with their financial performance. The aim of this part of the project, therefore, was to determine the effects debt-financing decisions have on financial performance of state-owned corporations in Kenya.

Debt financing refers to the mix of corporations' borrowed funds, which primarily consists of the long-term and short-term external finance used within the corporation. It is best explained by the capital structure decisions within the corporation, which involves debt-equity choice. Studies on this topic have revolved around the theory that certain financial policies, like debt financing, should either boost or hamper a corporation's competitive performance (Campello, 2006, p. 136). Assuming that debt is default-free and interest payments are tax-deductible, Modigliani and Miller (1963, p. 434) demonstrated that firms will increase their market values by increasing their use of debt financing. Most importantly, debt financing is the major source of new external funds for corporations (Denis \& Mihov, 2003, p. 4). Excessive use of debt, on the other hand, increases the financial risk of the corporation which, in turn, increases the bankruptcy costs (Myers, 1977, p. 148).

Few studies directly give the empirical relationship between a corporation's debt financing and its financial performance. Most of the studies, like Baltac1 and Ayaydin (2014, p. 54); Smith (2012, p. 157); Antoniou, Guney, and Paudyal (2008, p. 59); De Jong, Kabir, and Nguyen (2008, p. 1963) and Huang and Song (2006, p. 14) used profitability, which is a partial measure of financial performance to give empirical findings. They found that either there is a significant or non-significant negative relationship between leverage and the corporation's profitability. This implies that, as profitability (financial performance) increases, the corporation tends to use less debt, which is a contradiction of the "trade-off theory" and a confirmation of the "pecking-order theory".

Other studies also have found a positive relationship confirming the "trade-off theory" (Kouki \& Said, 2012, p. 221; (Gungoraydinoglu \& Öztekin, 2011, p. 1467). The studies by Fosu (2013, p. 146); Salim and Yadav (2012, p. 165); Chinaemerem and Odita (2012: 43) and Pratheepkanth (2011, p. 171), which have used other financial performance measures, like return on equity (ROE), return on assets (ROA) and return on investment (ROI), also found results of negative and positive relationships, indicating consistency with prior empirical studies. This study, therefore, used the common preferred accounting measures of financial performance like return on equity (ROE), return on investment (ROI) and return on assets (ROA) to assess how the debt financing decisions of state-owned corporations relate with their financial performance in Kenya. The study reviewed literature on debt financing theories, the relationship between debt financing and financial performance and debt financing practice within state-owned corporations, particularly in Kenya. In addition, the methodology applied for the study is highlighted followed by results and conclusions.

\section{DEBT FINANCING THEORIES}

Research on this topic has revolved around the assumption that certain financial policies, in particular, the use of debt financing, should either boost or hinder a firm's competitive performance (Campello, 2006, p. 136). Owing to this fact, Myers (2001, p. 81) argued that there is no universally accepted theory of debt-equity choice and there is no reason to expect one. However, he consented to the fact that there are several conditional theories which have been accepted. Most corporate finance literature point to the "trade-off theory", in which taxation and deadweight bankruptcy costs are taken into consideration (Frank \& Goyal, 2009, p. 1). According to this theory, corporations seek debt finance levels that balance the tax advantages of additional debt against the possible bankruptcy costs (Myers, 2001, p. 81). Myers (1984, p. 581), proposed the "pecking-order theory" in which there is preference of retained earnings, debt and then equity. Frank and Goyal (2009, p. 1) argued that the idea that firms engage in "market timing" has also become popular. According to Baker and Wurgler (2002: 1), in corporate finance, market timing refers to the exercise of issuing shares at high prices and repurchasing them at low prices with an intention of exploiting temporary fluctuations in the cost of equity relative to the cost of debt capital. Managers, therefore, have benefits to time the market if they think it is possible and if they care more about current equity owners. Finally, the "agency theory" lurks in the background of much of the theoretical discussion. Agency 
concerns are normally included in the trade-off framework when deduced broadly. Each theory has tried to explain the reasons behind the choice between debt financing and other forms of financing.

There are other theories which have been proposed. Jensen (1986, p. 324) developed the free cash flow theory in which he argued that free cash flows allowed firms' managers to finance projects earning low returns which might not be funded by the equity or bond markets, hence, reducing debt financing. Myers and Majluf (1984, p. 219) contributed to the asymmetric information hypothesis in debt financing. They argued that asymmetric information problems drive the capital structure of firms since managers know more than the rest of the market about their firm's value (information asymmetry) and the market penalizes the issuance of securities, including debt, whose benefits related to the assessment of such information. The theory argues that managers will issue securities in regard to their sensitivity towards information, issue more securities that are insensitive to information and fewer securities sensitive to information.

Berger, Ofek, and Yermack (2012, p. 1414) highlighted that there are theoretical arguments and some empirical evidence that point to the possibility that managers can become entrenched, and that they may deviate from choosing optimal debt financing as a result. The argument is referred to as managerial entrenchment theory, which suggests that entrenchment motives may cause managers to increase debt financing level beyond the optimal point, in order to inflate the voting power of their equity stakes and reduce the possibility of takeover attempts (Harris \& Raviv, 1988, p. 56). Since managerial entrenchment involves management control issues, it affects the agency costs and can be grouped under the agency costs theory of debt financing. Research on debt financing theories is yet to be concluded (Myers, 2001, p. 81). This study is, therefore, an additional contribution to the wealth of financial management epistemology already in existence in the area of debt financing.

\section{DEBT FINANCING AND FINANCIAL PERFORMANCE OF CORPORATIONS}

One of the key measures of a corporation's strength and growth is financial performance. Almost all stakeholders of a corporation are interested in the level of the corporation's financial performance. Therefore, strategies of the corporation, including debt financing, should be designed to increase the financial performance (rate of return on owner's investment) by generating a greater return on borrowed funds than the cost of using the funds. This kind of debt financing strategy is referred to as financial leverage (Damodaran 1999, p. 103). The strategy will have a positive effect if return on assets (ROA) is greater than the before-tax interest rate paid on debt. A negative effect will occur when a corporation generates a return on assets (ROA) that is less than the before-tax interest on debt. Studies on the relationship between corporations' financing choice and their performance often conclude that debt financing either hurts or boosts performance (Campello, 2006, p. 168). A study on corporations in the U.S. and in other countries revealed that debt financing potentially increases a corporation's value through the tax deductibility of interest (Kaplan \& Strömberg, 2008, p. 14).

According to debt financing theories, the relationship between debt-financing and financial performance of a corporation can either be positive or negative (Tudose, 2012, p. 78). Tudose (2012, p. 78) argued that static tradeoff theory, whose fundamental claim is that corporations set a target debt financing level which they attempt to reach, predicts a positive relationship between the debt financing level of a corporation and its financial performance. In addition, the agency costs theory advocates for debt financing as a way of disciplining managers as the debt financing level may be used to monitor managers and reduces agency costs (Berger \& Bonaccorsi di Patti, 2006, p. 1066). Thus, according to Tudose (2012, p. 78), it is to be expected that increased debt financing, in the perspective of reduced agency costs, may raise the level of efficiency and thereby contribute to upgrading firm performance.

Conversely, according to the pecking order theory, more profitable corporations generate higher earnings that can be used for self-financing, enabling them to opt less for debt financing (Lemmon \& Zender, 2010, p. 35). On the other hand, less profitable corporations may not enjoy the same opportunity and might be compelled to take on more debt financing in order to finance their ongoing activity. The pecking order theory, therefore, asserts a negative relationship between the debt-financing level and the financial performance of the corporation (Tudose, 2012, p. 78). Given the two propositions on how corporation debt financing relates with its financial performance, it would be important to also analyse the empirical findings from previous studies. 
The analysis of the results of empirical research indicates that the observations are contradictory, as they convey evidence both in favour of the positive relationship and in favour of the negative relationship between debt financing decisions and corporation performance (Tudose, 2012, p. 80). Therefore, empirical evidence has supported both propositions, especially when deferent measures of financial performance are applied. For example, Welch (2004, p. 123), using share price as the measure of corporations performance, found a positive relationship. Berger and Bonaccorsi di Patti (2006, p. 1097), also using profit efficiency as a corporation performance measure, found a positive relationship. Margaritis and Psillaki (2010, p. 628), using corporation's efficiency as performance measure, equally found a statistically significant positive relationship. San and Heng (2011, p. 34), studying large construction corporations, found a positive relationship when they used return on capital (ROC) and earnings per share (EPS) as measures of corporations' financial performance. Fosu (2013, p. 146), using return on assets (ROA), return on equity (ROE) and Tobin's q as a corporation's performance measure, also found a positive relationship between the debt-financing level and a corporation's performance. Park and Jang (2013, p. 59) also found a positive relationship while observing the interrelationships between free cash flow, diversification, debt financing and financial performance of corporations.

On the other hand, studies like Majumdar and Chhibber (1999, p. 297); Zeitun and Tian (2007, p. 44); King and Santor (2008, p. 2428); Salehi and Biglar (2009, p. 101); Obert and Olawale (2010, p. 1714); Akinlo and Asaolu (2012, p. 22); Norvaisiene (2012, p. 514) and Salim and Yadav (2012, p. 165) found a negative relationship between debt financing and a corporation's financial performance. Most of the studies used financial accounting measures of financial performance such as return on assets (ROA), return on equity (ROE), earnings per share (EPS) and operating profits. Thomas (2013, p. 45) used the graphical method to observe the relationship and found a behaviour that confirms the agency theory proposal. Thomas observed that debt increased with the increase of corporation performance, measured by earnings per share (EPS), up to some level (target debt), then declined as performance continued increasing steadily. This study used the common financial performance measures, such as return on asset (ROA), return on equity (ROE), and return on investment (ROI) with data from private-owned corporations .

Financial management decisions of state-owned corporations are influenced by both the economic factors and the state-enacted regulations. To some extent, the state corporations' managers are constantly tempted to base decisions on political rather than market criteria, and strategic state investment may be misdirected because of simple miscalculation (Fukuyama, 1995, p. 96). Boothman (1987, p. 302) argued that, until recently, governmentowned corporations have attracted minimal attention from management students. On the other hand, he agreed that there has been a growing appreciation of the significance of their role and uniqueness as an organisation type which stands between and combines the characteristics of public sector and private sector management. In Kenya, most of the state-owned corporations are being restructured and the majority are identified for privatisation (Debrah \& Toroitich, 2005, p. 210).

\section{STATE-OWNED CORPORATIONS IN KENYA}

In Kenya, the 206 state corporations are central to economic growth and are scattered within all the economic sectors in the republic. Their management, especially in the area of finance, will either boost or hamper the national economic growth (Hope, 2012, p. 129). Furthermore, in the last decade, a significant number of stateowned corporations in Kenya have been privatised and some are in the process, because of poor financial performance. The findings of this study will help the government to either continue with the privatisation programme or continue with the ongoing restructuring within state-owned corporations. According to Randa, Wagh, Sanghi, Umutesi, Opala, Mukuna, Nyamumbo, Karni, and Rabuku (2013, p. 4), the Kenyan financial sector is now the third largest in Sub-Saharan Africa (after South Africa and Nigeria) with a steady growth over the last decade. This has created an active financial sector with an open borrowing environment for both private and public sector corporations, including the state-owned corporations.

In acknowledging the role of state-owned corporations in Kenya, the report of the Kenyan presidential taskforce on state-owned corporations reforms (Republic of Kenya, 2013, p. x) identified five major roles that stateowned corporations play in Kenya. Firstly, state-owned corporations are important in promoting or accelerating economic growth and development. Secondly, these corporations are critical in building the capability and technical capacity of the state in facilitating and promoting national development. Thirdly, the corporations are important 
instruments in improving the delivery of public services, including meeting the basic needs of citizens. Fourthly, the state-owned corporations have been variously applied to the creation of good and widespread employment opportunities in various jurisdictions. Fifthly, the corporations are useful for targeted and judicious building of international partnerships. However, the report noted that the experience of state-owned corporations in Kenya, in trying to achieve these goals, has been, in some cases, successful and, in others, not so. Consequently, over the decades, different political regimes have tried to transform the state-owned corporations in Kenya so that they can fully play their significant role in the national development process.

On the other hand, data in the Kenyan presidential report, Republic of Kenya (2013, pp. xii-xiv), shows that the output of state-owned corporations to GDP, in nominal terms, has been increasing from 9.54\% in 2008/2009 to $11.64 \%$ in 2010/2011, based on internally-generated income. In terms of employment and wage earnings, formal wage employment in state-owned corporations in Kenya has been declining in both absolute numbers, as well as its share of the national formal wage employment. The report argued that this is, perhaps, a reflection of the withdrawal of the state from the sector through privatization efforts. On the other hand, data on average per capita annual wage earnings is rising faster than in the wider public sector or private sector, suggesting that the state-owned corporations sector pays more than even the private sector or the overall public sector. The report further argued that this is subjective evidence as to why, apart from the clear efficiency and effectiveness arguments, there is a demand for the establishment of more state corporations.

The presidential report further noted that, in 2011/12, eleven income-generating state-owned corporations made losses, compared to twelve in $2010 / 11$ and sixteen in 2009/10. This represents $21 \%$, 23\% and $31 \%$, respectively, of all income generating state-owned corporations. Highlighting the debt financing patterns, the report observed that the pattern of accumulation of publicly-guaranteed debt financing to state-owned corporations in Kenya shows a decline in 2007 from 2006, but has been on an upward trend since then. According to the report, the increase in this stock of debt is largely attributed to disbursements for creation of new infrastructure such as the Sondu Miriu Hydropower Project and the Kenya Ports Authority under the Mombasa Port Modernization Project. In addition, the report emphasised that it is important to note that, of the payments by the government on guaranteed debt in 2011/12, 95.6\% was on debt accruing to two state-owned corporations, pointing to significant defaults in payments.

Further, the Kenyan presidential report (Republic of Kenya (2013, p. xiv) noted that, from time to time, the Kenyan government treasury carries out loan restructuring of individual state-owned corporations, involving conversion of debt to equity or debt write-off and subsequent discharge of obligation of the corporations to repay or a combination of both. This increases the liabilities arising from state-owned corporations. The report acknowledged that, given growth plans of Kenya, under Kenya Vision 2030, it is expected that the level of debt within most of the state corporations will continue rising. The report argued that the key concern will be to enhance the efficiency and effectiveness in applying this debt to support the national development effort. Therefore, in recognition of the debt financing challenges facing the Kenyan state-owned corporations, this study attempted to determine whether their debt financing decisions affect their financial performance.

\section{METHODOLOGY}

\section{Research Design}

This study is a quantitative research, with the main purpose of testing the relationship between debt financing and financial performance of state-owned corporations, which is applied using inferential statistics tests (Struwig \& Stead, 2013, p. 4). According to Bryman (2012, pp. 75-78), quantitative research allows researchers to use independent and dependent variables to establish casual relationships between the constructs. In this case, this study applied the quantitative research to determine the causal relationship between the debt financing and financial performance of state-owned corporations. According to Struwig and Stead (2013, p. 5), causality is essential to quantitative researchers because they tend to take a normal scientific approach to research and, as such, the quantitative research is usually positivist. Positivism is a research paradigm that combines a deductive approach with a precise measurement of quantitative data, in order for researchers to identify the causal relationships which help in predicting human behaviour (Altinay \& Paraskevas, 2008, pp. 67-71). 
Further, Struwig and Stead (2013, p. 6) noted that there are many different types of research design but the common methods used to conduct quantitative research are exploratory, descriptive and experimental, among others. The research design applied in this study, therefore, was a combination of descriptive and explanatory research design, which reduced the limitations of non-experimental research by an inclusion of independent variables that are manipulated along with the measurement of dependent variables (Picardi \& Masick, 2014, p. 131). The independent variables in this study included debt financing levels, while the dependent variables included financial performance ratios.

In addition, the study applied a hybrid of cross sectional and longitudinal quantitative surveys. Rindfleisch, Malter, Ganesan and Moorman (2008, p. 276), in their study of cross-sectional versus longitudinal surveys, argued that both the designs have limitations and a combination will give a strong output. Therefore, the combination of the techniques allowed the researcher to investigate the constructs of the study, i.e., debt financing and financial performance, across the state-owned corporations and also derive the trend over a period of ten years from 2002 to 2012. To help in achieving the study objectives, the following research model was applied.

\section{Research Model}

In the process of determining the relationship between debt financing and financial performance of stateowned corporations, the study applied the multiple regression model 1. Most studies, like Majumdar and Chhibber (1999, p. 294); Zeitun and Tian (2007, p. 46); Margaritis and Psillaki (2010, p. 624); Akinlo and Asaolu (2012, p. 19); Salim and Yadav (2012, p. 159); Fosu (2013, p. 145) and Pervan and Mlikota (2013, p. 280), argued that a number of other factors, apart from debt financing, can have an impact on the financial performance of the corporation. These may be firm-specific or macroeconomic-related aspects, and have to be controlled. The objective is to control for other intrinsic and extrinsic factors which also impact on financial performance. In introducing the control variables in the model, the regression model 1 becomes more appropriate because it can incorporate the controlled variable as follows:

$Y_{i t}=a_{0}+\beta X_{i t}+\sum_{k=1}^{N} \gamma_{k} Z_{k i t}+\varepsilon_{i t}$

In this model, $Y_{i t}$ is now a measure of financial performance of corporation $i$ in year $t$ and $X$ represents the measure of the explanatory variable, i.e., debt financing (financial leverage). Variable $Z$ represents controlled factors (either firm-specific or macroeconomic), form $k=1$ to $N$ with their coefficients $\gamma$ to be estimated. $\alpha_{0}$ is the constant and $\beta$ is coefficient of the measure of explanatory variable $X$ which indicates the relationship between debt

financing and financial performance of the corporations. The financial performance measures and the measures of controlled variables commonly applied in the study are discussed under the section of variables and measures below.

\section{Variables and Measures}

Under model 1 above, debt financing is an explanatory (independent) variable. However, it has been noted under the literature review that many different empirical measures have been used to show debt financing levels within corporations (Frank \& Goyal, 2009, p. 2). They argued that some scholars advocate for book leverage, which is the proportion of corporation debt finance to the total book value of the assets of the corporation. Others scholars advocate for market leverage, which is the proportion of corporation debt to market value of the corporation. However, calculation of market values for corporations which are not listed in the stock exchange is not easy; this may make book value leverage popular for studies on unlisted corporations like Brav (2009, p. 274).

In addition to the aforementioned debate on the debt-financing level measure, varied studies also use deferent definitions of debt. Brav (2009, p. 273), Fan, Titman and Twite (2012, p. 33) and others use total debt as the numerator while De Jong, Kabir and Nguyen (2008, p. 1956) and others use long- term debt. There are other studies, like Huang and Song (2006, p. 21) and Jõeveer (2013, p. 299), which used both long-term debt and total debt as numerators of the leverage ratio. Since Fama and French (2002, p. 9) and Rajan and Zingales (1995, p. 1429) suggested that reliance on book leverage is not a serious limitation and most of the state corporations in Kenya are not listed in the stock exchange, this study applied the book leverage and definitions of debt, i.e., long-term, shortterm and total debt, as debt financing level proxies. As summarised in table 1, the study used book values to measure 
long-term debt leverage (LDL) using long-term debt of the state corporation divided by the total assets, short-term debt leverage (SDL) using short-term debt of the state corporation divided by the total assets and total debt leverage (TDL) using total debt of the state corporation divided by the total assets.

The financial performance variables, as applied under model 1 , were dependent variables while debtfinancing (financial leverage) variables and the controlled factors were explanatory (independent) variables. According to Rao, Al-Yahyaee, and Syed (2007, p. 9), most management researchers favour accounting measures of financial performance, such as return on equity (ROE) return on investment (ROI), and return on assets (ROA), along with the changeability in those returns measures.

As indicated in table 1, this study used these accounting financial performance measures. The financial performance measure and the controlled variables proxies used are those commonly used by debt financing and financial performance studies such as Jõeveer (2013, p. 299), Fan, Titman and Twite (2012, p. 33), Rao, AlYahyaee, and Syed (2007, p. 9) and Huang and Song (2006, p. 21). The return on equity (ROE) was measured by net profit (earnings after tax) divided by equity, return on assets (ROA) was measured by operating profits divided by total assets and return on investment (ROI) was measured using net profit (earning after tax) divided by total assets (Surroca et al., 2010, p. 44; Norvaisiene, 2012, p. 514). The controlled explanatory variables applied were other factors influencing financial performance. These included corporation size (SIZ), asset tangibility (TANG), corporation growth (GROW), corporation risk (RISK), liquidity (LIQ), inflation (INFL) and corporation age (AGE).

Table 1. Research variables and measures

\begin{tabular}{lcl}
\hline \multicolumn{1}{c}{ Variable } & Measure & \\
\hline Debt financing levels (financial leverage) & & Formulae (Proxy) \\
\hline Total debt leverage & TDL & Total debt/Total assets \\
Long-term debt leverage & LDL & Long-term debt/Total assets \\
Short-term debt leverage & SDL & Short-term debt/Total assets \\
\hline Controlled explanatory variables & & \\
\hline Corporation size & SIZ & Natural logarithm of total assets \\
Asset tangibility & TANG & Tangible assets/Total assets \\
Corporation growth & GROW & Percentage (\%) change in total assets \\
Corporation risk & RISK & Standard deviation of operating profits/Total assets \\
Liquidity & LIQ & Current assets/Current liabilities \\
Inflation rate & INFL & Annual average inflation rate \\
Age & AGE & Number of years in existence \\
\hline Financial performance & & \\
\hline Return on assets & ROA & Operating profit/Total assets \\
Return on investment & ROI & Net profit (profit after tax)/Total assets \\
Return on equity & ROE & Net profit (profit after tax)/Equity \\
\hline
\end{tabular}

Table 1 represents the research variables and measures, followed by their proxies.

\section{Research Hypotheses}

The study tested the following hypotheses:

$\mathbf{H}_{01}$ : There is no relationship between debt financing and ROA;

$\mathbf{H}_{\mathbf{0 2}}$ : There is no relationship between debt financing and ROI; and

$\mathbf{H}_{\mathbf{0 3}}$ : There is no relationship between debt financing and ROE.

\section{Target Population and Sample Size}

The population of this study was defined in terms of the number of state-owned corporations established by the Acts of Parliament in Kenya as at June 30, 2011. The population frame data was from the office of the Inspector General in charge of state corporations under the Ministry of Public Service in the office of the Prime Minister of Kenya. According to this data, there are 206 established state corporations in Kenya, out of which 50 are income- 
generating corporations (state-owned corporations). Hence, the target population for this study was made up of the 50 income-generating state corporations in Kenya as at $31^{\text {st }}$ December 2011.

The sample size for the study is made up of 40 income-generating corporations, selected from the general population using the stratified non-probability sampling technique. The non-income generating corporations are excluded from the study, since their financial performance is not profit based and may not be influenced by marketoriented decisions, such as debt financing strategies. Struwig and Stead (2013, p. 116) argued that the nonprobability sampling technique should be used in special cases, usually when the population has much in common, like the case of income-generating state corporations.

\section{Data Analysis}

The cross-sectional secondary data, extracted from the financial statements obtained from the financial managers or the Ministry of Finance Office and the state-owned corporations' websites were used as secondary data for the regression analysis. The regression analysis was applied using the conceptual model 1, to determine the relationship between debt financing and financial performance of state-owned corporations in Kenya. In addition, to establish the significance of the variables in the regression model, the $t$-test was applied at $90 \%, 95 \%$ and $99 \%$ levels of confidence.

The common regression model estimator, from the reviewed literature, appears to be the pooled ordinary least squares (OLS) method and the generalized method of moments (GMM). However, this study estimated the coefficients of multiple regression model using the independent and dependent variables of the study, through the fixed effects (FE), random effects (RE) and GMM system panel regression models. According to Bond (2002, pp. 141-142), panel data models have an advantage over pooled ordinary least squares (OLS_ENREF_30) model since the former incorporates the cross-sectional and longitudinal variables of the model. The panel data advantages over pooled ordinary least squares (OLS), therefore, include the possibility that underlying microeconomic dynamics (heterogeneity) may be concealed by pooling biases, and the scope panel data offers to investigate heterogeneity in adjustment dynamics between different types of individuals, household or corporations.

On the other hand, Lemma and Negash (2013, p. 1092) argued that empirical literature favours fixed effects (FE) over random effects (RE) in basic debt-financing research, since the fixed effects allow for controls on biasness that may be caused by the corporation's specific characteristics and time effects. However, fixed effects assume that the time-invariant characteristics are unique to the specific corporation and should not be correlated with other corporation's characteristics. Therefore, each corporation is assumed to be different and the corporation's error term and the constant (which captures individual corporation's characteristics) should not be correlated with each other. If the error terms are correlated i.e., endogeneity exists, then the fixed effects model is not suitable since inferences may not be correct. Therefore, there is need to model the relationship by using either random effects or GMM.

The Hausman test is applied to test whether the error terms are correlated with the constants. If the test is significant, at $95 \%$ level of confidence $(\mathrm{p}<0.05)$, then there is no correlation and the fixed effects model figures are reliable. However, Greene (2008, p. 183) argued that if there is reason to believe that differences across entities (corporations) have some influence on the dependent variables (like, in this case, financial leverage or financial performance), then the random effects method is appropriate. In addition, random effects allow for the inclusion of time invariant variables, such as gender. In contrast, the random effects model assumes that the individual (variables) characteristics are not correlated by the time effects (i.e., there is no autocorrelation or serial correlation) and there is need to specify those individual (corporation's) characteristics that may or may not influence the predictor variables. The problem with this is that some variables may not be available, therefore, leading to omitted variable bias in the model. All the same, the random effects model allows for generalization of the inferences beyond the sample used in the model.

As aforementioned, it has been observed that endogeneity is a common problem that econometric model research, such as debt financing, has to deal with. In regard to this observation, Lemma and Negash (2013, p. 1092) argued that modern debt-financing research should apply system-GMM procedures, which are robust to data 
endogeneity problems (Antoniou et al., 2008, p. 61; Baltacı \& Ayaydın, 2014, p. 51; Dang, 2013, p. 175; Gaud, Hoesli, \& Bender, 2007, p. 206; Gaud, Jani, Hoesli, \& Bender, 2005, p. 58; Gungoraydinoglu \& Öztekin, 2011, p. 1462; Mateev, Poutziouris, \& Ivanov, 2013, p. 42; Öztekin \& Flannery, 2012, p. 90).

In other words, the system-GMM estimator controls for the presence of unobserved firm-specific effects and for the endogeneity of explanatory variables (Mateev et al., 2013, p. 42). According to Bond (2002, p. 160), the system-GMM method is particularly useful when the panel regression model of interest contains endogenous or predetermined explanatory variables, but the processes generating these series are not completely specified. Therefore, a specification test is done to show that the excluded variables have explanatory power for the righthand-side endogenous variables, the instruments are uncorrelated with the error term and that the exclusion restrictions are valid. Lastly, the specification test helps to show that there are endogenous explanatory variables in the model since system-GMM is inefficient relative to OLS if all variables are exogenous.

Further, the system-GMM estimator can be used to obtain consistent parameter estimates in a wide range of micro-econometric applications, including debt financing strategies of state-owned corporations. However, Bond (2002, p. 160) noted that the estimator may be subject to large finite sample biases when the instruments available are weak, and this is particularly likely to be a problem when using the basic first differenced estimator with series that are highly persistent, like the case in this study. Therefore, a careful comparison of the consistent of systemGMM regression estimator results with other panel regression models, like fixed effects and random effects, can help in avoiding more biases in the study results. In addition, the use of these different panel data regression estimator models helped to check the robustness of the results.

Under the system-GMM estimator procedure, the form of panel regression equation 1, for the relationship between debt financing and financial performance, will be changed into equation 2 , as follows

$$
Y_{i t}=a_{0}+\lambda Y_{i t-1}+\beta X_{i t}+\sum_{k=1}^{N} \gamma_{k} \mathrm{Z}_{k i t}+\varepsilon_{i t}
$$

Where the new variable $Y_{i t-1}$ is the lagged value of the dependent variable, i.e., lagged value of financial performance for equation 2, with its coefficient $\lambda$. The presence of the lagged dependent variable $Y_{i t-1}$ controls for autocorrelation or serial correlation within the dependent variables.

In addition, the regression analysis process required data cleaning in order to achieve better results. Since the debt financing procedures of state-owned corporations within the financial sector are unique, the data from nine state-owned corporations from the financial sector were excluded from the regression analysis (Alzomaia, 2014, p. 59; Lemma \& Negash, 2013, p. 1093). Further, for a better trend analysis, the data from financial statements used in the regression analysis included figures for the ten-year period from 2002 to 2012, subject to availability of the statements.

The data analysis was done using Data analysis and Statistically Software (STATA) for the fixed effects, random effects and system-GMM regression models. In the analysis of GMM panel data regression model, the Arellano-Bond GMM estimator in STATA software was applied, since, in addition to the aforementioned benefits of using system-GMM estimator, it was designed for small-time series (T), in this case, a minimum of 3 years and a maximum of 11 years, and large cross-sectional individual observations $(\mathrm{N})$, in this case, 31 non-financial stateowned corporations.

\section{RESULTS}

\section{Regression}

The regression analysis process required data cleaning in order to eliminate outliers that may influence results. Since the debt financing procedures of state-owned corporations within the financial sector are unique, the data from these nine state-owned corporations were excluded from the regression analysis (Alzomaia, 2014, p. 59; Lemma \& Negash, 2013, p. 1093). Further, for a better trend analysis, the data from financial statements used in the regression analysis included figures for the eleven-year period from 2002 to 2012, subject to availability of the 
statements. The number of state-owned corporations for the regression analysis reduced to 31, which makes up $62 \%$ of the target population and $77.5 \%$ of the study sample size. Table 2 demonstrates the summary statistics for the regression analysis used for determining the relationship between debt financing and financial performance within the state-owned corporations in Kenya. The table also shows that the maximum observations for the variables is 202 and the minimum is 174, indicating some variables have missing figures whose effects are controlled by the STATA software in the regression analysis.

Table 2 shows that the means for total debt leverage (TDL), long-term debt leverage (LDL) and short-term debt leverage (SDL) are $0.641,0.337$ and 0.3052 , respectively. The table shows the mean of negative profitability by financial performance measures, such as return on equity (ROE) and return on investment (ROI), except for return on assets (ROA). These negative means confirm the Kenyan presidential report on state corporations (Republic of Kenya 2013: xii-xiv), which also indicated that the state-owned corporations have been making losses during this period.

Interestingly, Table 2 also shows that liquidity (LIQ), which is measured by current assets as a fraction of current liabilities, is 4.874, which indicates a better short-term solvency (Colin, Stephen, Randolph and Bradford 2012, pp. 50-51). This result indicates high overall liquidity amongst the state-owned corporations. This pattern could be an indication of low external debt financing within the corporations and more of internal financing supported by the pecking order theory (Murray Z \& Vidhan K, 2008, p. 158). Table 2 shows the overall growth rate (GROW) of state-owned corporations, measured as a percentage change in total assets, at $15.65 \%$ over the period, indicating the need for financing the long-term investment expansions.

Table 2. Regression analysis summary statistics

\begin{tabular}{lrcccc}
\hline \multicolumn{1}{c}{ Variable } & Mean & Std. Dev. & Min & Max & Observations \\
\hline TDL & 0.6407 & 0.7099 & 0.0014 & 2.8261 & 201 \\
LDL & 0.3374 & 0.5696 & 0 & 2.6522 & 201 \\
SDL & 0.3052 & 0.3950 & 0.0013 & 2.75 & 201 \\
SIZ & 22.3640 & 1.6479 & 16.8112 & 25.7984 & 202 \\
TANG & 0.5358 & 0.2407 & 0 & 0.9583 & 202 \\
GROW & 15.6531 & 47.6608 & -47.6379 & 350.007 & 174 \\
RISK & 0.0797 & 0.1232 & 0 & 1 & 180 \\
LIQ & 4.8742 & 14.8634 & 0.0142 & 191.0231 & 201 \\
INFL & 11.6149 & 6.9892 & 0 & 26.2 & 202 \\
AGE & 3.1930 & 0.8012 & 0 & 4.1896 & 202 \\
ROA & 0.0131 & 0.2161 & -2.6 & 0.2997 & 201 \\
ROE & -0.0081 & 4.5142 & -48.3803 & 41.1437 & 201 \\
ROI & -0.0035 & 0.2136 & -2.6 & 0.2990 & 201 \\
\hline
\end{tabular}

\section{Correlation Analysis}

Table 3 presents the Pearson correlation coefficients $(r)$ for the panel data regression analysis variables used in the study. The table presents all the variables used in identification of the factors influencing debt financing, in the determination of the relationship between financial leverage and financial performance, and in the identification of the debt financing theories within the state-owned corporations in Kenya. The symbols ***,**, and * indicate significance at the $99 \%, 95 \%$ and $90 \%$ levels, respectively.

Table 3 shows that debt financing measures of total debt leverage (TDL) and short-term debt leverage (SDL) are significantly negatively correlated with the financial performance measures of return on assets (ROA) and return on investment (ROI), though not strongly. In addition, the long-term debt leverage (LDL) is also negatively correlated with ROA and ROI, but are very weak and not significant. However, there is a conflicting correlation between the financial leverage measure and the financial performance measure of return on equity (ROE). Table 3 shows a positive correlation between ROE and, TDL and SDL, while the correlation with LDL is negative. Further, the correlations between ROE and these financial leverage measures are not significant. Hence, ROE is not a good variable for determining the relationship between financial leverage and financial performance of state-owned corporations in Kenya. 
Table 3. Correlation analysis

\begin{tabular}{|c|c|c|c|c|c|c|c|c|c|}
\hline & TDL & LDL & SDL & SIZ & TANG & GROW & RISK & LIQ & INFL \\
\hline TDL & 1 & & & & & & & & \\
\hline LDL & $0.8415^{* * *}$ & 1 & & & & & & & \\
\hline SDL & $0.6451^{* * * *}$ & $0.1301^{*}$ & 1 & & & & & & \\
\hline SIZ & $0.383^{* * *}$ & $0.2958^{* * *}$ & $0.2842^{* * *}$ & 1 & & & & & \\
\hline TANG & $0.2592^{* * *}$ & $0.3065^{* * *}$ & 0.0408 & $0.7536^{* * *}$ & 1 & & & & \\
\hline GROW & 0.0626 & -0.0429 & $0.1683^{* *}$ & $0.1644^{* *}$ & 0.0402 & 1 & & & \\
\hline RISK & $0.3563^{* * *}$ & $0.2286^{* * * *}$ & $0.3291^{* * * *}$ & $0.2452^{* * * *}$ & $0.2308^{* * *}$ & -0.0435 & 1 & & \\
\hline LIQ & -0.0724 & -0.0125 & $-0.1151^{*}$ & 0.1025 & $0.1449^{*}$ & 0.0293 & $0.1953^{* * *}$ & 1 & \\
\hline INFL & $0.26^{* * * *}$ & $0.1546 * *$ & $0.2574^{* * *}$ & $0.5885^{* * * *}$ & $0.4122^{* * *}$ & $0.1637^{* *}$ & $0.2089^{* * * *}$ & 0.0626 & 1 \\
\hline AGE & 0.0922 & 0.0816 & 0.0539 & -0.0524 & $-0.1793^{* *}$ & $-0.1965^{* * * *}$ & -0.0825 & $-0.2306^{* * * *}$ & -0.0207 \\
\hline ROA & $-0.2576^{* * *}$ & 0.021 & $-0.4999^{* * *}$ & $0.0872^{*}$ & 0.1082 & 0.0597 & $-0.6149^{* * *}$ & 0.0926 & 0.0302 \\
\hline ROE & 0.045 & -0.0213 & 0.1128 & 0.0084 & -0.0855 & 0.0431 & 0.0831 & 0.0317 & 0.0411 \\
\hline \multirow[t]{2}{*}{ ROI } & $-0.3519^{* * *}$ & -0.0925 & $-0.5127^{* * *}$ & $0.0328^{*}$ & 0.0504 & 0.0791 & $-0.6535^{* * *}$ & 0.0987 & 0.0132 \\
\hline & AGE & ROA & ROE & & & & & & \\
\hline AGE & 1 & & & & & & & & \\
\hline ROA & -0.0492 & 1 & & & & & & & \\
\hline ROE & $-0.1189 *$ & -0.1033 & 1 & & & & & & \\
\hline ROI & -0.0636 & $0.9723^{* * *}$ & $-0.1153^{*}$ & & & & & & \\
\hline
\end{tabular}

For the controlled explanatory variables, Table 3 demonstrates that the financing leverage measures, TDL, LDL and SDL, are positively and significantly correlated with several measures. These factors include corporation size (SIZ), asset tangibility (TANG), corporation risk (RISK) and inflation rate (INFL). In addition, the table also highlights a non-significant positive correlation between corporation growth (GROW) and corporation age (AGE), and TDL and SDL.

Further, Table 3 also shows that there are weak positive and negative significant correlations between financial performance measures (i.e., ROI and ROA) and controlled variable measures of SIZ and RISK, respectively. However, the table shows a strong significant negative correlation between financial performance measures (i.e., ROI and ROA). Interestingly, the correlation coefficient of ROE and most variables, except AGE, are not significant. These results indicate why ROE is not a popular measure of financial performance in debt-financing analysis. The Pearson correlation coefficients (r) reported in Table 3 only show the pair-wise relationship between the variables used in the study regression analysis. Therefore, to help in determining the relationship between debt financing and financial performance, the panel data regression analysis was applied using the fixed effects (FE), random effects (RE) and system-GMM panel data regression model estimators.

\section{The Relationship between Debt Financing and Financial Performance}

The financial performance of state-owned corporations in Kenya was measured using the accounting variables. These variables include return on assets (ROA), return on equity (ROE) and return on investments (ROI). Each variable of the financial performance was applied under the panel regression model 1 as a dependent variable with the controlled variables, which may also influence financial performance, and financial leverage taken as explanatory variables. Therefore, for each financial performance panel regression model, debt financing (i.e., TDL, LDL and SDL), corporation size (SIZ), asset tangibility (TANG), corporation growth (GROW), corporation risk (RISK), liquidity (LIQ), inflation (INFL) and age (AGE) were taken as explanatory variables using the panel regression model 1 . The regression analysis was done using the fixed effects (FE), random effects (RE) and systemGMM procedures and reported under the three different measures of financial leverage (TDL, LDL and SDL).

The results for the regression analysis of the relationship between financial performance variables, such as return on asset (ROA), return on investment (ROI) and return on equity (ROE), and the total debt leverage (TDL), are reported in Table 4, while Table 5 represents the relationship between the same financial performance variables (ROA, ROI, and ROE) and the long-term debt leverage (LDL). The relationship between financial performance variables and short-term debt leverage (SDL) are reported in table 6. 


\section{The Relationship between Financial Performance and Total Debt Leverage}

Table 4 presents the regression results for the relationship between financial performance and total debt leverage (TDL) within the state-owned corporations in Kenya. The table also includes the other explanatory variables, such as corporation size (SIZ), asset tangibility (TANG), corporation growth (GROW), corporation risk (RISK), liquidity (LIQ), inflation (INFL) and corporation age (AGE). It also presents the validity and reliability tests (i.e., $\mathrm{R}^{2}$ Wald chi2 (F), AR (1\&2) and Sargan test) for the models. The table presents the financial performance (ROA, ROI and ROE) under three panel regression models (Fixed effects, Random effects and system-GMM). ***, $* *$, and $*$ indicate significance at the $99 \%, 95 \%$ and $90 \%$ levels, respectively.

Table 4 shows that financial performance, under the more advanced panel regression model estimator (system-GMM model), is negatively related to total debt leverage of state-owned corporations in Kenya. The negative results are confirmed by the financial performance models under return on assets (ROA), return on investment (Debrah \& Toroitich) and return on equity (ROE). The negative relationship results are very significant and consistent, under the financial performance measures, such as return on assets (ROA) and return on investment (ROI). The results under the fixed effects (FE) and the random effects (RE) models are significantly strong, with both ROA and ROI, highlighting a significant coefficient of about -0.7 (-70\% variation), under the FE model, and 0.3 ( $-30 \%$ variation), under the RE model. However, the coefficient between financial performance measures, including ROE, and total debt leverage (TDL) is not very strong ( $-20 \%$ or -0.2$)$, though significant under ROA and ROE.

Table 4 also shows some positive relationship results between the financial performance measure of ROE and total debt leverage, under the fixed effects (FE) and random effects (RE) models. This positive relationship highlighted by the ROE is not significant and the model's R-sq. of about 0.23 , indicates that only $23 \%$ of the variance in financial performance (ROE) is explained by the independent variables, including debt financing. Therefore, ROE is not a strong model for measuring financial performance in this case.

On the other hand, ROA and ROI models, both under FE and RE, highlight very strong $\mathrm{R}^{2}$ values of about $0.82(82 \%)$ and very strong significant $\mathrm{F}$ tests of 0.000 , under each case. These reliability and validity tests indicate the ROA and ROI are better models in determining the relationship between debt financing and financial performance of the state-owned corporations in Kenya. Their significant negative relationship results can be interpreted in line with the pecking order theory of debt financing. According to the pecking order theory, more profitable state-owned corporations generate higher earnings that can be used for self-financing, enabling them to opt less for debt financing (Lemmon \& Zender, 2010, p. 35).

Less profitable, state-owned corporations may not enjoy the same opportunity and might be compelled to take on more debt financing in order to finance their ongoing activity. The pecking order theory, therefore, asserts a negative relationship between the debt financing level and the financial performance of the corporation (Tudose, 2012, p. 78). However, the insignificant results of FE and RE models, under ROE, may be a sign but not a proof of the agency costs theory. The agency costs theory advocates for debt financing as a way of disciplining managers of state-owned corporations, as the debt financing level may be used to monitor managers and reduces agency costs (Berger \& Bonaccorsi di Patti, 2006, p. 1066). Thus, according to Tudose (2012, p. 78), it is to be expected that increased debt financing, in the perspective of reduced agency costs, may raise the level of efficiency and thereby contribute to upgrading firm performance, making the relationship positive. In addition to the debt financing effects on financial performance of state-owned corporations in Kenya, Table 4 shows other variables that affect their financial performance. The corporation size (SIZ), corporation growth (GROW) and liquidity (LIQ) are significant factors that affect their financial performance positively, while corporation risk (RISK) affects it negatively. 
Table 4. Relationship between financial performance and total debt leverage

\begin{tabular}{|c|c|c|c|c|c|c|c|c|c|}
\hline \multirow[b]{2}{*}{ Variable } & \multicolumn{3}{|c|}{ Fixed effects (FE) } & \multicolumn{3}{|c|}{ Random effects (RE) } & \multicolumn{3}{|c|}{ System-GMM } \\
\hline & ROA & ROI & ROE & ROA & ROI & ROE & ROA & ROI & ROE \\
\hline Ll. & & & & & & & 0.0626 & -0.0734 & $-0.4894 * * *$ \\
\hline TDL & $-0.6781 * * *$ & $-0.6829 * * *$ & 0.3288 & $-0.1945^{* * *}$ & $-0.1832 * * *$ & 0.3287 & $-0.0705 * * *$ & $-0.0971 * * *$ & -0.0992 \\
\hline SIZ & 0.0413 & 0.0645 & -2.0393 & 0.0254 & 0.0171 & -0.3732 & $0.0342 * * *$ & $0.0240 * * *$ & $0.2251 * * *$ \\
\hline TANG & 0.0658 & 0.0220 & 3.5482 & 0.1348 & 0.0973 & -0.3816 & 0.0530 & 0.0276 & $-1.2819 * *$ \\
\hline GROW & $0.0009 * * *$ & $0.0008 * * *$ & $0.0221 *$ & $0.0013 * * *$ & $0.0013 * * *$ & 0.0071 & $0.0006^{* *}$ & $0.0005^{*}$ & $-0.0090 * * *$ \\
\hline RISK & $-0.3762 * *$ & $-0.3591 * *$ & $-41.3990 * *$ & $-0.6831 * * *$ & $-0.6984 * * *$ & $-14.0834 * * *$ & -0.2645 & $-0.5151 * * *$ & $11.7845^{* * *}$ \\
\hline LIQ & -0.00001 & -0.0002 & 0.0150 & 0.0011 & 0.0011 & 0.0008 & $0.0014 *$ & $0.0014 *$ & $-0.0135 * *$ \\
\hline INFL & 0.0005 & 0.0008 & 0.0143 & 0.0010 & 0.0012 & -0.0088 & 0.0013 & 0.0016 & 0.0207 \\
\hline AGE & 0.1511 & 0.0662 & -0.7469 & 0.0290 & 0.0127 & -0.2904 & 0.0045 & -0.0096 & $-0.6660 * * *$ \\
\hline Constant & -0.9998 & $-1.2403^{*}$ & 46.8966 & -0.5964 & -0.3595 & $10.4068 *$ & $-0.7643 * * *$ & $-0.4593 * *$ & $-2.8002 *$ \\
\hline Observations & 171 & 171 & 171 & 171 & 171 & 171 & 162 & 162 & 162 \\
\hline $\mathrm{R}^{2}$ & 0.8136 & 0.8094 & 0.3283 & 0.6871 & 0.6727 & 0.3058 & & & \\
\hline Hausman test-Prob>chi2 & $0.001 * * *$ & $0.000 * * * *$ & $0.0041 * * *$ & $0.001 * * *$ & $0.000 * * * *$ & $0.0041 * * *$ & & & \\
\hline Prob $>F($ Wald chi2) & $0.000 * * *$ & $0.000 * * *$ & $0.000 * * *$ & $0.000 * * *$ & $0.000 * * *$ & $0.0295 * *$ & $0.000 * * *$ & $0.000 * * *$ & $0.000 * * *$ \\
\hline $\operatorname{AR}(1) \operatorname{Pr}>z$ & & & & & & & $0.000 * * *$ & $0.045 * *$ & $0.026 * *$ \\
\hline $\mathrm{AR}(2) \operatorname{Pr}>\mathrm{z}$ & & & & & & & 0.877 & 0.978 & 0.588 \\
\hline Sargan test-Prob > chi2 & & & & & & & 0.000 & 0.000 & 0.000 \\
\hline
\end{tabular}




\section{The Relationship between Financial Performance and Long-Term Debt Leverage}

The negative relationship between debt financing and financial performance of state-owned corporations can also be observed in Table 5 using the long-term debt leverage (LDL) results. Though the validity and reliability tests of $\mathrm{R}^{2}$ are low (less than 0.5) under the fixed effects (FE) and random effects (RE) models, there is consistency of the negative sign under the models, including the system-GMM. However, the financial performance measure of ROE highlights a positive sign under the random effects (RE) model.

Table 5 presents the regression results for the relationship between financial performance and long-term debt leverage (LDL) within the state-owned corporations in Kenya. The table also includes the other explanatory variables, such as corporation size (SIZ), asset tangibility (Tangcharoensathien et al.), corporation growth (GROW), corporation risk (RISK), liquidity (LIQ), inflation (INFL) and corporation age (AGE). It also presents the validity and reliability tests (i.e., $\mathrm{R}^{2}$, Wald chi2 (F), AR (1\&2) and the Sargan test) for the models. The table presents the financial performance (ROA, ROI and ROE) under three panel regression models (Fixed effects, Random effects and system-GMM). ***,**, and * indicate significance at the $99 \%, 95 \%$ and $90 \%$ levels, respectively.

As aforementioned, the negative relationship result highlighted under the long-term debt leverage (LDL) is a further indication of the application of the pecking order theory within the state-owned corporations in Kenya. According to the pecking order theory, more profitable state-owned corporations generate higher earnings that can be used for self-financing, enabling them to opt less for long-term debt financing (Lemmon \& Zender, 2010, p. 35). The element of an agency costs theory is also highlighted by the positive result of ROE under RE.

This implies that the state-owned corporations may be advocating for long-term debt financing as a way of disciplining managers, as the long-term debt financing level may be used to monitor managers and reduces agency costs, hence, increasing financial performance (Berger \& Bonaccorsi di Patti, 2006, p. 1066). Table 5 also shows other variables, such as corporation size (SIZ), asset tangibility (TANG), and corporation growth (GROW), as significant factors that affect the financial performance of state-owned corporations in Kenya. The corporation size (SIZ), asset tangibility (TANG) and corporation growth (GROW) affect financial performance positively, while corporation risk (RISK) affects it negatively. 
Table 5. Relationship between financial performance and long-term debt leverage

\begin{tabular}{|c|c|c|c|c|c|c|c|c|c|}
\hline \multirow[b]{2}{*}{ Variable } & \multicolumn{3}{|c|}{ Fixed effects (FE) } & \multicolumn{3}{|c|}{ Random effects (RE) } & \multicolumn{3}{|c|}{ System-GMM } \\
\hline & ROA & ROI & ROE & ROA & ROI & ROE & ROA & ROI & ROE \\
\hline Ll. & & & & & & & 0.0520 & -0.0282 & $-0.4893 * * *$ \\
\hline LDL & -0.0246 & -0.0195 & -0.3595 & -0.0006 & -0.0260 & 0.2502 & -0.0101 & -0.0211 & $-0.4047 * *$ \\
\hline SIZ & $0.1482 * *$ & $0.1726 * * *$ & -2.6876 & $0.0319 * *$ & $0.0233 *$ & -0.3909 & $0.0386 * * *$ & $0.0297 * * *$ & $0.2318 * * *$ \\
\hline TANG & $0.5226 * * *$ & $0.4814 * * *$ & 1.5371 & 0.0874 & 0.0627 & -0.4559 & 0.0413 & 0.0337 & $-1.1338 * *$ \\
\hline GROW & $0.0017 * * *$ & $0.0017 * * *$ & $0.0179 *$ & $0.0010 * * *$ & $0.0009 * *$ & 0.0072 & $0.0006 *$ & $0.0006 * *$ & $-0.0092 * * *$ \\
\hline RISK & $-0.9924 * * *$ & $-0.9789 * * *$ & $-38.6646 * * *$ & $-0.6629 * * *$ & $-0.6735 * * *$ & $-13.8802 * * *$ & $-0.3628 * *$ & $-0.5548 * * *$ & $11.9232 * * *$ \\
\hline LIQ & $0.0018 *$ & 0.0017 & 0.0066 & $0.0020 *$ & $0.0020^{*}$ & -0.0013 & $0.0020 * *$ & $0.0021 * *$ & $-0.0133 * *$ \\
\hline INFL & 0.0017 & 0.0020 & 0.0088 & 0.0013 & 0.0014 & -0.0089 & 0.0016 & 0.0018 & 0.0199 \\
\hline AGE & -0.0993 & -0.1873 & 0.8331 & 0.0103 & -0.0016 & -0.2961 & -0.0019 & -0.0120 & $-0.6358 * * *$ \\
\hline Constant & $-3.2401 * * *$ & $-3.5043 * *$ & $59.8878 * *$ & $-0.7800^{* *}$ & $-0.5396^{*}$ & $10.9844 *$ & $-0.8849 * * *$ & $-0.6436 * * *$ & $-3.0523 *$ \\
\hline Observations & 171 & 171 & 171 & 171 & 171 & 171 & 162 & 162 & 162 \\
\hline & 0.4901 & 0.4914 & 0.3176 & 0.4216 & 0.4041 & 0.3 & & & \\
\hline Hausman test-Prob>chi2 & $0.000 * * *$ & $0.000 * * *$ & $0.0086^{* * *}$ & $0.000 * * *$ & $0.000 * * *$ & $0.0086 * * *$ & & & \\
\hline Prob $>$ F (Wald chi2) & $0.000 * * *$ & $0.000 * * *$ & $0.0001 * * *$ & $0.000 * * *$ & $0.000 * * *$ & $0.0322 * *$ & $0.000 * * *$ & $0.000 * * *$ & $0.000 * * *$ \\
\hline $\operatorname{AR}(1) \operatorname{Pr}>z$ & & & & & & & $0.000 * * *$ & $0.000 * * *$ & $0.017 * *$ \\
\hline $\operatorname{AR}(2) \operatorname{Pr}>z$ & & & & & & & 0.864 & 0.975 & 0.575 \\
\hline Sargan test-Prob $>$ chi2 & & & & & & & $0.000 * * *$ & $0.000 * * *$ & $0.000 * * *$ \\
\hline
\end{tabular}




\section{The Relationship between Financial Performance and Short-Term Debt Leverage}

Table 6 presents the regression results for the relationship between financial performance and short-term debt leverage (SDL) within the state-owned corporations in Kenya. The table also includes the other explanatory variables, such as corporation size (SIZ), asset tangibility (TANG), corporation growth (GROW), corporation risk (RISK), liquidity (LIQ), inflation (INFL) and corporation age (AGE). It also presents the validity and reliability tests (i.e., $\mathrm{R}^{2}$, Wald chi2 (F), AR (1\&2) and the Sargan test) for the models.

A further significant negative relationship between financial performance and debt financing is highlighted by the short-term leverage (SDL) results in Table 6 . The table shows a significant negative relationship between financial performance measures of ROA and ROI, and short-term debt leverage (SDL), under all the models (FE, $\mathrm{RE}$ and system-GMM). The negative relationship of ROA and ROI is very strong under the FE and RE, reporting coefficients of $-0.6(-60 \%$ variation) and $-0.4(-40 \%$ variation), respectively. However, the negative relationship of the same measures (ROA and ROI) have slightly strong coefficients of about -0.3 ( $-30 \%$ variation), which are also very significant.

Just like the results under total debt leverage (TDL) and long-term debt leverage (LDL), the financial performance measure of ROE also highlights a positive relationship with the short-term debt leverage (SDL). Though not significant, the positive relationship coefficients under all the models (FE, RE and system-GMM) are strong, at about 0.6 (60\% variation), for each case. This is an indication that, though the state-owned corporations of Kenya's debt financing strategies may be explained by the pecking order theory, the element of agency costs theory cannot be totally ignored. It, therefore, implies that more profitable state-owned corporations generate higher earnings that can be used for self-financing, enabling them to opt less for short-term debt financing. On the other hand, there is also an indication that, in the case of insufficient self-financing, the profitable state-owned corporations use more of short-term debt than the long-term type of debt financing.

Table 6 also highlights the other state-owned corporation factors that affect their financial performance. The table reports significant results for corporation size (SIZ), corporation growth (GROW) as other factors that affect the financial performance of state-owned corporations positively. On the other hand, corporation risk (RISK) and corporation age (AGE) affect financial performance negatively. These consistent results of other corporation factors influencing state-owned financial performance is a good test of robustness for the financial models under TDL, LDL and SDL.

Further, the negative significant results on the relationship between debt financing and financial performance are also highlighted by introducing the profitability (PROF) measure used under factors of debt financing as a measure of financial performance. The significant negative relationship between financial performance (PROF) and debt financing is also reported under all the debt-financing measures (TDL, LDL and SDL). The combined results for all financial performance measures, including profitability (PROF), are included under the section of appendices.

In general, the regression results for fixed effects (FE), random effects (RE) and system-GMM show that there is a significant negative relationship between financial debt financing and financial performance of stateowned corporations in Kenya. Studies by Majumdar and Chhibber (1999, p. 297); Zeitun and Tian (2007, p. 44); King and Santor (2008, p. 2428); Salehi and Biglar (2009, p. 101); Obert and Olawale (2010, p. 1714); Akinlo and Asaolu (2012, p. 22); Norvaisiene (2012, p. 514) and Salim and Yadav (2012, p. 165) found a negative relationship between debt financing and a corporation's financial performance using the ROA. Most of the studies also used financial accounting measures of financial performance such as return on assets (ROA.), return on equity (ROE), earnings per share (EPS) and operating profits. This is in line with the pecking order theory of debt financing.

However, the few positive signs under the return on equity measures in the study results may be an indication of the agency theory. Thomas (2013, p. 45) used the graphical method to observe the relationship and found a behaviour that confirms the agency theory proposal. Thomas observed that debt increased with the increase of corporation financial performance, up to some level (target debt), then declined as performance continued increasing steadily. Therefore, a further study should be done to identify whether the pecking order theory or the agency theory, under the trade-off model, is applicable in the explanation of debt-financing strategies within the state-owned corporations. 
Table 6. Relationship between financial performance and short-term debt leverage

\begin{tabular}{|c|c|c|c|c|c|c|c|c|c|}
\hline \multirow[b]{2}{*}{ Variable } & \multicolumn{3}{|c|}{ Fixed effects (FE) } & \multicolumn{3}{|c|}{ Random effects (RE) } & \multicolumn{3}{|c|}{ System-GMM } \\
\hline & ROA & ROI & ROE & ROA & ROI & ROE & ROA & ROI & ROE \\
\hline $\mathrm{Ll}$. & & & & & & & -0.0202 & $-0.1392 * *$ & $-0.4884 * * *$ \\
\hline SDL & $-0.6113 * * *$ & $-0.6190 * * *$ & 0.7052 & $-0.3813 * * *$ & $-0.3594 * * *$ & 0.5187 & $-0.2619 * * *$ & $-0.2805 * * *$ & 0.5806 \\
\hline SIZ & $0.1053 * *$ & $0.1288 * * *$ & -2.2952 & 0.0136 & 0.0055 & -0.3623 & $0.0227 * * *$ & 0.0119 & $0.2690 * * *$ \\
\hline TANG & 0.0241 & -0.0226 & 4.3501 & -0.0299 & -0.0520 & -0.1917 & -0.0435 & -0.0733 & $-1.1201 * *$ \\
\hline GROW & $0.0009 * * *$ & $0.0009^{* * *}$ & $0.0225^{*}$ & $0.0011 * * *$ & $0.0011 * * *$ & 0.0070 & $0.0006^{* *}$ & $0.0005^{* *}$ & $-0.0091 * * *$ \\
\hline RISK & $-0.3293 *$ & $-0.3084^{*}$ & $-42.4247 * *$ & $-0.5098 * * *$ & $-0.5483^{* * *} *$ & $-14.0873 * * *$ & $-0.3100 * *$ & $-0.5726 * * *$ & $11.3916^{* * *}$ \\
\hline LIQ & -0.0001 & -0.0003 & 0.0177 & 0.0003 & 0.0003 & 0.0014 & 0.0005 & 0.0005 & -0.0092 \\
\hline INFL & 0.0005 & 0.0008 & 0.0157 & 0.0007 & 0.0012 & -0.0093 & 0.0014 & 0.0017 & 0.0214 \\
\hline AGE & -0.0246 & -0.1103 & 0.0069 & 0.0107 & -0.0059 & -0.2526 & -0.0095 & $-0.0261 *$ & $-0.6612 * * *$ \\
\hline Constant & $-2.0918 *$ & $-2.3337 * * *$ & $50.7575 *$ & -0.1859 & 0.0390 & 9.9916 & $-0.3667 * *$ & $-0.0506 *$ & $-4.1291 * *$ \\
\hline Observations & 171 & 171 & 171 & 171 & 171 & 171 & 162 & 162 & 162 \\
\hline R-sq & 0.7754 & 0.7748 & 0.3328 & 0.7465 & 0.7331 & 0.3092 & & & \\
\hline Hausman test-Prob $>$ chi 2 & $0.000 * * *$ & $0.000 * * *$ & $0.0027 * * *$ & $0.000 * * *$ & $0.000 * * *$ & $0.0027 * * *$ & & & \\
\hline Prob > F (Wald chi2) & $0.000 * * *$ & $0.000 * * *$ & $0.000 * * *$ & $0.000 * * *$ & $0.000 * * *$ & $0.0306 * *$ & $0.000 * * *$ & $0.000 * * *$ & $0.000 * * *$ \\
\hline $\mathrm{AR}(1) \mathrm{Pr}>\mathrm{z}$ & & & & & & & $0.000 * * *$ & $0.075^{*}$ & $0.010 * * *$ \\
\hline $\operatorname{AR}(2) \operatorname{Pr}>z$ & & & & & & & 0.333 & 0.675 & 0.689 \\
\hline Sargan test-Prob $>$ chi2 & & & & & & & $0.000 * * *$ & $0.000 * * *$ & $0.000 * * *$ \\
\hline
\end{tabular}




\section{CONCLUSION}

It can be concluded for the study results that debt financing strategies within state-owned corporations in Kenya have a negative effect on their financial performance. Therefore, null hypotheses $H_{01}$ and $H_{02}$ of the study were rejected and their respective alternative hypotheses: $H_{11}$ : There is a negative relationship between debt financing and ROA; $H_{12}$ : There is a negative relationship between debt financing and ROI; and the null hypothesis $H_{03}$ : There is no relationship between debt financing and $R O E$, were accepted. The pecking order theory suggests that corporations with high financial performance generate more earnings that are used for self-financing, enabling them to go for less debt financing (Lemmon \& Zender, 2010, p. 35). This implies that state-owned corporations in Kenya with better financial performance have less debt levels, since they may be using self-generated resources to finance their investments. In addition, the agency cost theory can also explain this negative relationship. Agency costs can also exist from conflicts between debt and equity holders when there is a risk of default amongst the stateowned corporations with high levels of debt. This risk of default may create underinvestment which, in effect, tends to reduce the financial performance of the corporations.

However, the positive results of ROE may also be an implication of agency theory. This is an indication that though the debt-financing strategies of state-owned corporations in Kenya may be explained by the pecking order theory, the element of agency costs theory cannot be totally ignored. Therefore, the state-owned corporations in Kenya, with high levels of debt financing, may use them to reduce the agency costs of outside equity and increase the financial performance of the corporation by constraining or encouraging managers to act more on the interest of the existing shareholder, mostly the government. In general, the relationship between debt financing and financial performance of state-owned corporations was found to be negative, which is a common phenomena, especially when corporations are pursuing the pecking order and agency theories. However, the element of political influence in the state-owned corporations' debt-financing decisions may be one of the factors implying that as much as the management of the state-owned corporations would want to follow the economic market factors in making financial management decisions, they still have to please their political masters. A further study should be done to determine the effect of political influence on financial management decisions, such as debt financing.

\section{AUTHOR INFORMATION}

Dr. Micah Odhiambo Nyamita is Faculty of Management Sciences in the Department of Public Management and Economics. Dr. Nyamita has just completed his full-time Public Management doctoral degree at Durban University of Technology. He also serves as a part-time lecturer in the department of Management Accounting and Business Unit within the university. Prior to his doctoral programme, he served at a private accounting university in Kenya (KCA University), rising from the level of assistant lecturer to the level of Deputy Centre Director in one of the main KCA University campuses.

Micah has been a business lecturer, specialising in the area of financial accounting, management accounting, financial management, taxation and auditing for professional examinations (CPA (K) and ACCA) and academic students, both at postgraduate and undergraduate levels for the last 9 years. He also served as a part-time lecturer for some Kenyan public universities such as Maseno University, Jomo Kenyatta University of Technology, Bondo University of Technology and Baraton University of Eastern Africa-Rwanda.

Micah aspires to contribute towards fostering financial management teaching and research in both public and private sectors. E-mail: mnyamita@yahoo.com

Professor Nirmala Dorasamy is Faculty of Management Sciences at the Department of Public Management and Economics. Professor Dorasamy is Full Professor in the Department of Public Management and Economics at the Durban University of Technology. She lectures in the undergraduate and postgraduate programmes at DUT, Public Administration Leadership and Management Academy (PALAMA) and the Department of Defence.

The focus area of her research is ethics and public sector management, with an emphasis on enhancing the effectiveness and efficiency of public service delivery underpinned by a strong sense of governance within a democratic dispensation. Her international linkages involve collaborative research with the Swinburne University of Technology, Federation University and Monash University in Australia, and the American University in Cairo. The 
focus of this international collaboration is linked to governance, leadership excellence and ethical practices. She has successfully supervised and graduated eight Masters and three Doctoral students. Professor Dorasamy has developed resource material for the Department of Defence and Business Studies Unit at the DUT. She has co-authored textbooks for senior secondary learners and books for higher education purposes and she has published in local and international journals as well as presented papers at national and international conferences. She has been a keynote speaker and session chair at the Rajiv Academy, India. Professor Dorasamy has also presented the conference communiqué for the African Association of Public Administration and Management (AAPAM).

In 2013, she was the recipient of the Top Researcher Award in the Faculty Management Sciences and was nominated for an academic development scholarship from Mendel University, Czech Republic. E-mail: nirmala@dut.ac.za

Dr Hari Lall Garbharran is Faculty of Accounting and Informatics at the Department of Management Accounting. Dr. Garbharran is the Research Co-ordinator and Chair of the Research Committee in the Faculty of Accounting and Informatics. He has lectured in Research Methodology to postgraduate students. Currently, he supervises Masters and Doctoral students in the Faculties of Accounting and Informatics and Management Sciences.

His areas of research focus on Public Administration, Business Administration and Management Accounting. His current interests include the transformation of financial administration within South Africa municipalities for the achievement of unqualified audits. He has successfully supervised and graduated 14 Masters and 3 Doctoral students. He has published and presented papers both locally and internationally. He has co-authored textbooks for senior secondary learners. He serves as a reviewer for papers in national and international journals. Dr Garbharran also assists University staff and students with the editing and proofreading of journal articles for publication. E-mail: GarbharranHL@dut.ac.za/garbharranhl@gmail.com

\section{REFERENCES}

Akinlo, O., \& Asaolu, T. (2012). Profitabilty and leverage: Evidence from Nigerian firms. Global Journal of Business Research (GJBR), 6(1), 17-25.

Altinay, L., \& Paraskevas, A. (Eds.). (2008). Planning Research in Hospitality and Tourism (1st ed.). UK: Elsevier Ltd.

Alzomaia, T. S. F. (2014). Capital Structure Determinats of Publicly Listed Companies in Saudi Arabia. International Journal of Business \& Finance Research (IJBFR), 8(2), 53-67.

Antoniou, A., Guney, Y., \& Paudyal, K. (2008). The determinants of capital structure: capital market-oriented versus bank-oriented institutions. Journal of financial and quantitative analysis, 43(1), 59-92.

Baltac1, N., \& Ayaydın, H. (2014). Firm, Country and Macroeconomic Determinants of Capital Structure: Evidence from Turkish Banking Sector. EMAJ: Emerging Markets Journal, 3(3), 47-58.

Berger, A. N., \& Bonaccorsi di Patti, E. (2006). Capital structure and firm performance: A new approach to testing agency theory and an application to the banking industry. Journal of Banking \& Finance, 30(4), 1065-1102.

Berger, P. G., Ofek, E., \& Yermack, D. L. (2012). Managerial entrenchment and capital structure decisions. The Journal of Finance, 52(4), 1411-1438.

Bond, S. R. (2002). Dynamic panel data models: a guide to micro data methods and practice. Portuguese economic journal, 1(2), 141-162.

Boothman, B. E. (1987). Strategy formation in Canadian government corporations in business. Paper presented at the Academy of Management Best Papers Proceedings: 302-306

Brav, O. (2009). Access to capital, capital structure, and the funding of the firm. The Journal of Finance, 64(1), 263308.

Bryman, A. (2012). Social research methods (4th ed.): Oxford university press.

Campello, M. (2006). Debt financing: Does it boost or hurt firm performance in product markets? Journal of Financial Economics, 82(1), 135-172.

Cassar, G. (2004). The financing of business start-ups. Journal of Business Venturing, 19(2), 261-283.

Chinaemerem, O. C., \& Odita, A. (2012). Impact of capital structure on the financial performance of Nigerian firms. Arabian Journal of Business and Management Review (OMAN Chapter), Vol. 1, 43-61. 
Chong, K.-M., Dolley, C., Houghton, K., \& Monroe, G. S. (2009). Effect of outsourcing public sector audits on costefficiency. Accounting \& Finance, 49(4), 675-695.

Colin, F., Stephen, R., Randolph W., W. and Bradford D., J. 2012. Fundamentals of Corporate Finance. 5 th South African Edition ed. Berkshire: McGraw-Hill Education (UK) Limited.

Dang, V. A. (2013). Testing capital structure theories using error correction models: evidence from the UK, France and Germany. Applied Economics, 45(2), 171-190.

De Jong, A., Kabir, R., \& Nguyen, T. T. (2008). Capital structure around the world: The roles of firm-and countryspecific determinants. Journal of Banking \& Finance, 32(9), 1954-1969.

Debrah, Y. A., \& Toroitich, O. K. (2005). The making of an African success story: The privatization of Kenya Airways. Thunderbird International Business Review, 47(2), 205-230.

Denis, D. J., \& Mihov, V. T. (2003). The choice among bank debt, non-bank private debt, and public debt: evidence from new corporate borrowings. Journal of Financial Economics, 70(1), 3-28.

Fama, E. F., \& French, K. R. (2002). Testing trade-off and pecking order predictions about dividends and debt. Review of financial studies, 15(1), 1-33.

Fan, J. P. H., Titman, S. and Twite, G. (2012). An International Comparison of Capital Structure and Debt Maturity Choices. Journal of Financial \& Quantitative Analysis, 47 (1): 23-56.

Foster, M. D. and Young, M. T. (2013). Capital Structure Determinants for Emerging Markets by Geographic Region. Journal of Applied Financial Research, 1: 55-87.

Fosu, S. (2013). Capital structure, product market competition and firm performance: Evidence from South Africa. The Quarterly Review of Economics and Finance, 53(2), 140-151.

Frank, M. Z., \& Goyal, V. K. (2009). Capital structure decisions: which factors are reliably important? Financial Management, 38(1), 1-37.

Fuerst-Waltl, B., \& Fuerst, C. (2012). Effect of inbreeding depression on survival of Austrian Brown Swiss calves and heifers. Journal of Dairy Science, 95(10), 6086-6092.

Fukuyama, F. (1995). Social capital and the global economy. Foreign affairs, 74(5), 89-103.

Gaud, P., Hoesli, M., \& Bender, A. (2007). Debt-equity choice in Europe. International Review of Financial Analysis, 16(3), 201-222.

Gaud, P., Jani, E., Hoesli, M., \& Bender, A. (2005). The Capital Structure of Swiss Companies: an Empirical Analysis Using Dynamic Panel Data. European Financial Management, 11(1), 51-69.

Goswami, G., \& Shrikhande, M. M. (2001). Economic exposure and debt financing choice. Journal of Multinational Financial Management, 11(1), 39-58.

Greene, H. W. (2008). Econometric analysis (6th ed.). Upper Saddle River, New Jersey: Prentice Hall.

Gungoraydinoglu, A., \& Öztekin, Ö. (2011). Firm- and country-level determinants of corporate leverage: Some new international evidence. Journal of Corporate Finance, 17(5), 1457-1474.

Guthrie, J., \& Olson, O. (1999). Debating developments in New Public Financial Management: The limits of global theorising and. Financial Accountability \& Management, 15(3/4), 209-228.

Harris, M., \& Raviv, A. (1988). Corporate control contests and capital structure. Journal of Financial Economics, 20(0), 55-86.

Hompesch, M., Morrow, L., Watkins, E., Roepstorff, C., Thomsen, H. F., \& Haahr, H. (2014). Pharmacokinetic and Pharmacodynamic Responses of Insulin Degludec in African American, White, and Hispanic/Latino Patients With Type 2 Diabetes Mellitus. Clinical Therapeutics, 36(4), 507-515.

Hope, K. R. (2012). Managing the Public Sector in Kenya: Reform and Transformation for Improved Performance. Journal of Public Administration \& Governance, 2(4), 128-143.

Huang, G., \& Song, F. M. (2006). The determinants of capital structure: evidence from China. China Economic Review, 17(1), 14-36.

Jensen, M. C. (1986). Agency costs of free cash flow, corporate finance, and takeovers. The American economic review, 323-329.

Jõeveer, K. (2013). Firm, country and macroeconomic determinants of capital structure: Evidence from transition economies. Journal of Comparative Economics, 41, 294-308.

Kaplan, S. N., \& Strömberg, P. (2008). Leveraged buyouts and private equity Working Paper 14207. 1050 Massachusetts Avenue Cambridge, MA 02138: National Bureau of Economic Research.

Kettl, D. F., \& Milward, B. H. (1996). The state of public management (1st ed.). United States of America: The Johns Hopkins University press. 
King, M. R., \& Santor, E. (2008). Family values: Ownership structure, performance and capital structure of Canadian firms. Journal of Banking \& Finance, 32(11), 2423-2432.

Kouki, M., \& Said, H. B. (2012). Capital Structure Determinants: New Evidence from French Panel Data. International Journal of Business \& Management, 7(1), 214-229.

Lemma, T. T., \& Negash, M. (2013). Institutional, macroeconomic and firm-specific determinants of capital structure: The African evidence. Management Research Review, 36(11), 1081-1122.

Lemmon, M. L., \& Zender, J. F. (2010). Debt capacity and tests of capital structure theories. Journal of Financial and Quantitative Analysis, 45(5), 1-49.

Majumdar, S. K., \& Chhibber, P. (1999). Capital structure and performance: Evidence from a transition economy on an aspect of corporate governance. Public Choice, 98(3-4), 287-305.

Margaritis, D., \& Psillaki, M. (2010). Capital structure, equity ownership and firm performance. Journal of Banking \& Finance, 34(3), 621-632.

Mateev, M., Poutziouris, P., \& Ivanov, K. (2013). On the determinants of SME capital structure in Central and Eastern Europe: A dynamic panel analysis. Research in International Business and Finance, 27(1), $28-51$.

Modigliani, F., \& Miller, M. H. (1963). Corporate income taxes and the cost of capital: a correction. The American Economic Review, 53(3), 433-443.

Murray Z, F., \& Vidhan K, G. (2008). Trade-off and pecking order theories of debt. Handbook Of Corporate Finance: Empirical Corporate Finance, 2, 135-202.

Myers, S. C. (1977). Determinants of corporate borrowing. Journal of Financial Economics, 5(2), 147-175.

Myers, S. C. (1984). The capital structure puzzle. The Journal of Finance, 39(3), 574-592.

Myers, S. C. (2001). Capital structure. The Journal of Economic Perspectives, 15(2), 81-102.

Myers, S. C., \& Majluf, N. S. (1984). Corporate financing and investment decisions when firms have information that investors do not have. Journal of Financial Economics, 13(2), 187-221.

Norvaisiene, R. (2012). The Impact of Capital Structure on the Performance Efficiency of Baltic Listed Companies. Kapitalo struktūros ịtaka Baltijos šalių listinguojamu įmonių veiklos efektyvumui., 23(5), 505-516.

Nyamita, M. O., Garbharran, H. L. and Dorasamy, N. (2014). Factors influencing debt financing decisions of corporations-theoretical and empirical literature review. Problems and Perspectives in Management, 12 (4): 189-202.

Obert, M., \& Olawale, F. (2010). Does debt really matter on the profitability of small firms? A perspective on small manufacturing firms in Bulawayo, Zimbabwe. African Journal of Business Management, 4(9), 1709-1716.

Öztekin, Ö., \& Flannery, M. J. (2012). Institutional determinants of capital structure adjustment speeds. Journal of financial economics, 103(1), 88-112.

Park, K., \& Jang, S. (2013). Capital structure, free cash flow, diversification and firm performance: A holistic analysis. International Journal of Hospitality Management, 33(0), 51-63.

Pervan, M., \& Mlikota, M. (2013). What determines the profitability of companies: Case fo Croatian food and beverage industry. Ekonomska istraživanja, 26(1), 277-286.

Picardi, C. A., \& Masick, K. D. (2014). Research Methods: Designing and conducting research with a real-World Focus. U.S.A.: SAGE Publications, Inc.

Pratheepkanth, P. (2011). Capital structure and financial performance: Evidence from selected business companies in Colombo stock exchange Sri Lanka. Journal of Arts, Science \& Commerce, 11(2), 171-183.

Rajan, R. G., \& Zingales, L. (1995). What do we know about capital structure? Some evidence from international data. The journal of Finance, 50(5), 1421-1460.

Rajan, R. G., \& Zingales, L. (2012). What do we know about capital structure? Some evidence from international data. The Journal of Finance, 50(5), 1421-1460.

Randa, J., Smita, W., Apurva, S., Umutesi, A., Kennedy Mukuna, O., Nyamumbo, M., . . Sophie, R. (2013). Reinvigorating growth with a dynamic banking sector. World Bank Working Paper, 1, 1-82.

Rao, N. V., Al-Yahyaee, K. H. M., \& Syed, L. A. (2007). Capital structure and financial performance: evidence from Oman. Indian Journal of Economics and Business, 6(1), 1.

Republic of Kenya. (2013). Report of the Presidential Taskforce on Parastatal Reforms. Nairobi: Kenya Government Press, Retrieved from http://www.cofek.co.ke/Report\%20of\%20The\%20Presidential\%20Task\%20force\%20on\%20Parastatal\%20 Reforms.pdf.

Rindfleisch, A., Malter, A. J., Ganesan, S., \& Moorman, C. (2008). Cross-sectional versus longitudinal survey research: concepts, findings, and guidelines. Journal of Marketing Research, 45(3), 261-279. 
Salehi, M., \& Biglar, K. (2009). Study of the relationship between capital structure measures and performance: evidence from Iran. International Journal of Business and Management, 4(1), 97-103.

Salim, M., \& Yadav, R. (2012). Capital Structure and Firm Performance: Evidence from Malaysian Listed Companies. Procedia - Social and Behavioral Sciences, 65(0), 156-166.

San, O. T., \& Heng, T. B. (2011). Capital structure and corporate performance of Malaysian construction sector. International Journal of Humanities and Social Science, 1(2), 28-36.

Singh, A. (1995). Corporate financial patterns in industrializing economies. IFC Technical paper(2).

Smith, G. P. (2012). Capital Structure Determinants for Tax-Exempt Organisations: Evidence from the UK. Financial Accountability \& Management, 28(2), 143-163.

Struwig, F. W., \& Stead, G. B. (2013). Research: Planning , Designing and Reporting. South Africa: Pearson Education South Africa (Pty) Ltd 2013.

Surroca, J., Tribó, J. A., \& Waddock, S. (2010). Corporate responsibility and financial performance: The role of intangible resources. Strategic Management Journal, 31(5), 463-490.

Tangcharoensathien, V., Patcharanarumol, W., Ir, P., Aljunid, S. M., Mukti, A. G., Akkhavong, K., . . Mills, A. Health-financing reforms in southeast Asia: challenges in achieving universal coverage. The Lancet, 377(9768), 863-873.

Thomas, A. E. (2013). Capital Structure and Financial Performance of Indian Cement Industry. BVIMR Management Edge, 6(2), 44-50.

Tudose, M. B. (2012). Capital Structure and Firm Performance. Economy Transdisciplinarity Cognition, 15(2), 7682.

Wang, H., Liddell, C. A., Coates, M. M., Mooney, M. D., Levitz, C. E., Schumacher, A. E., . . Murray, C. J. L. Global, regional, and national levels of neonatal, infant, and under-5 mortality during 1990-2013: a systematic analysis for the Global Burden of Disease Study 2013. The Lancet, 384(9947), 957-979.

Welch, I. (2004). Capital structure and stock returns. Journal of Political Economy, 112(1), 106-132.

Zeitun, R., \& Tian, G. G. (2007). Capital structure and corporate performance: evidence from Jordan. Australasian Accounting Business and Finance Journal, 1(4), 40-61. 


\section{APPENDIX A: ADDITIONAL TABLES FOR REGRESSION RESULTS}

Relationship between total debt leverage (TDL) and financial performance regression results

Table A1.1. Fixed effects (FE) results

\begin{tabular}{|c|c|c|c|c|c|}
\hline Factor & PROF & ROA & ROI & NPM & ROE \\
\hline \multicolumn{6}{|l|}{ Ll. } \\
\hline TDL & $-0.6404287 * * *$ & $-0.6780392 * * *$ & $-0.6829241 * * *$ & $-0.72879 * * *$ & 0.32881 \\
\hline SIZ & 0.0108278 & 0.0412881 & 0.0645249 & 0.0819856 & -2.039297 \\
\hline TANG & -0.3601457 & 0.0657767 & 0.0219828 & $-0.5136169 * *$ & 3.548249 \\
\hline GROW & 0.0004696 & $0.0008531 * * *$ & $0.0008277 * * *$ & 0.0000847 & $0.0220535 *$ \\
\hline RISK & 0.3301606 & $-0.3761709 * *$ & $-0.3591025 * *$ & 0.1123134 & $-41.39899 * *$ \\
\hline LIQ & 0.000355 & $-6.80 \mathrm{E}-06$ & -0.0001749 & 0.0017733 & 0.0150242 \\
\hline INFL & $-0.0097598 *$ & 0.0005365 & 0.0007979 & -0.0002212 & 0.0143184 \\
\hline AGE & -0.0381454 & 0.1510628 & 0.066215 & -0.1510209 & -0.7468906 \\
\hline Constant & 0.5173076 & -0.9997809 & $-1.240257 *$ & -0.6829529 & 46.89658 \\
\hline Observations & 171 & 171 & 171 & 171 & 171 \\
\hline R-sq & 0.0954 & 0.7136 & 0.7094 & 0.4783 & 0.2283 \\
\hline rho & 0.61788373 & 0.93322037 & 0.92553584 & 0.72337045 & 0.3988165 \\
\hline Hausman test-Prob>chi 2 & 0.2766 & $0.001 * * *$ & $0.000 * * * *$ & $0.0041 * * *$ & $0.0041 * * *$ \\
\hline Prob > F (Wald chi2) & 0.095 & $0.000 * * *$ & $0.000 * * *$ & $0.000 * * *$ & $0.000 * * *$ \\
\hline
\end{tabular}

Table A1.2.Random effects (RE) results

\begin{tabular}{|c|c|c|c|c|c|}
\hline Factor & PROF & ROA & ROI & NPM & ROE \\
\hline Ll. & & & & & \\
\hline TDL & $-0.2819357 * *$ & $-0.1944738 * * *$ & $-0.1832352 * * *$ & $-0.4696054 * * *$ & 0.3286714 \\
\hline SIZ & $0.1425663 * *$ & 0.0254161 & 0.0170668 & $0.0650785^{* *}$ & -0.3731956 \\
\hline TANG & -0.3328532 & 0.1347631 & 0.0973117 & $-0.3411909 * *$ & -0.3815357 \\
\hline GROW & 0.0003841 & $0.0013033 * * *$ & $0.0012656 * * *$ & 0.000349 & 0.0071229 \\
\hline RISK & 0.5873171 & $-0.6830627 * * *$ & $-0.6984457 * * *$ & 0.0026092 & $-14.08341 * * *$ \\
\hline LIQ & 0.0016782 & 0.0010732 & 0.0010533 & $0.0026794 *$ & 0.0008005 \\
\hline INFL & -0.0086587 & 0.0009098 & 0.0011799 & -0.000193 & -0.0087545 \\
\hline AGE & -0.0191591 & 0.0289745 & 0.0127335 & -0.0789885 & -0.2904479 \\
\hline Constant & $-2.810087 * *$ & -0.5963575 & -0.3595143 & -0.8255132 & $10.4068 *$ \\
\hline Observations & 171 & 171 & 171 & 171 & 171 \\
\hline R-sq & 0.0702 & 0.5871 & 0.5727 & 0.4698 & 0.2058 \\
\hline rho & 0.47716898 & 0.33358659 & 0.24470305 & 0.54859338 & 0 \\
\hline Hausman test-Prob>chi 2 & 0.2766 & $0.001 * * *$ & $0.000 * * * *$ & $0.0041 * * *$ & $0.0041 * * *$ \\
\hline Prob > F (Wald chi2) & 0.036 & $0.000 * * *$ & $0.000 * * *$ & $0.000 * * * *$ & 0.0295 \\
\hline
\end{tabular}


Table A1.3. System-GMM results

\begin{tabular}{|c|c|c|c|c|c|}
\hline Factor & PROF & ROA & ROI & NPM & ROE \\
\hline Ll. & $0.0899425 * * *$ & 0.0626016 & -0.0734183 & $0.0476823 * * *$ & $-0.4893936 * * *$ \\
\hline TDL & $-0.0926595 *$ & $-0.0705313 * * *$ & $-0.0970552 * * *$ & $-0.262587 * * *$ & -0.0991515 \\
\hline SIZ & $0.1816567 * * *$ & $0.0341641 * * *$ & $0.0240033 * * *$ & $0.0822112 * * *$ & $0.2250762 * * *$ \\
\hline TANG & $-0.4838912 * *$ & 0.052972 & 0.0275833 & $-0.2243256 * *$ & $-1.28193 * *$ \\
\hline GROW & 0.0002709 & $0.0006011 * *$ & $0.0004835 *$ & -0.0002667 & $-0.008985 * * *$ \\
\hline RISK & $1.252295 * *$ & -0.2645159 & $-0.5150955 * * *$ & $0.5666948 * *$ & $11.78448 * * *$ \\
\hline LIQ & 0.0008909 & $0.0014445 *$ & $0.0014228 *$ & $0.0032433 * *$ & $-0.0134825 * *$ \\
\hline INFL & -0.009308 & 0.0013453 & 0.0015825 & -0.0016741 & 0.0206635 \\
\hline $\mathrm{AGE}$ & -0.0449462 & 0.0044628 & -0.0096178 & $-0.0611206 * *$ & $-0.6660834 * * *$ \\
\hline Constant & $-3.63905 * * *$ & $-0.7642905 * * *$ & $-0.4592925 * *$ & -1.445746 & $-2.800169 *$ \\
\hline Observations & 162 & 162 & 162 & 162 & 162 \\
\hline Prob > F (Wald chi2) & $0.000 * * *$ & $0.000 * * *$ & $0.000 * * *$ & $0.000 * * *$ & $0.000 * * *$ \\
\hline $\operatorname{AR}(1) \operatorname{Pr}>z$ & $0.011 * *$ & $0.000 * * *$ & 0.345 & $0.000 * * *$ & $0.026 *$ \\
\hline $\operatorname{AR}(2) \operatorname{Pr}>z$ & 0.836 & 0.877 & 0.978 & 0.480 & 0.588 \\
\hline Sargan test-Prob $>$ chi2 & 0.007 & 0.000 & 0.000 & 0.000 & 0.000 \\
\hline
\end{tabular}

Relationship between long-term debt leverage (LDL) and financial performance regression results

Table A2.1. Fixed effects (FE) results

\begin{tabular}{|c|c|c|c|c|c|}
\hline Factor & PROF & ROA & ROI & NPM & ROE \\
\hline \multicolumn{6}{|l|}{$\mathrm{Ll}$. } \\
\hline LDL & -0.0854004 & -0.0245806 & -0.0194912 & 0.1867851 & -1.359508 \\
\hline SIZ & 0.1062964 & $0.1481534 * *$ & $0.1726233 * * *$ & $0.2156008 * *$ & -2.687582 \\
\hline TANG & 0.0799356 & $0.5226114 * * *$ & $0.4813815 * * *$ & -0.0520303 & 1.53706 \\
\hline GROW & 0.0012702 & $0.0017036 * * *$ & $0.0016846 * * *$ & 0.0010081 & $0.0178645^{*}$ \\
\hline RISK & -0.262585 & $-0.9924149 * * *$ & $-0.9788812 * * *$ & -0.5134227 & $-38.66464 * * *$ \\
\hline LIQ & 0.0021278 & $0.0018444 *$ & 0.0016876 & $0.0036798 *$ & 0.0066244 \\
\hline INFL & -0.0086647 & 0.0016918 & 0.0019611 & 0.0010068 & 0.0088109 \\
\hline AGE & -0.2592675 & -0.0993286 & -0.1872829 & $-0.4728877 *$ & 0.8331044 \\
\hline Constant & -1.5093 & $-3.240098 * * *$ & $-3.50429 * *$ & $-3.397619 * *$ & $59.88772 * *$ \\
\hline Observations & 171 & 171 & 171 & 171 & 171 \\
\hline $\mathrm{R}-\mathrm{sq}$ & 0.0442 & 0.3901 & 0.3914 & 0.2619 & 0.2176 \\
\hline rho & 0.56414746 & 0.80563368 & 0.84602244 & 0.82330554 & 0.39575736 \\
\hline Hausman test-Prob $>$ chi 2 & 0.7349 & $0.000 * * *$ & $0.000 * * *$ & $0.0015 * * *$ & $0.0086 * * *$ \\
\hline Prob > F (Wald chi2) & 0.6366 & $0.000 * * *$ & $0.000 * * *$ & $0.0024 * * *$ & $0.0001 * * *$ \\
\hline
\end{tabular}

Table A2.2: Random effects (RE) results

\begin{tabular}{|c|c|c|c|c|c|}
\hline Factor & PROF & ROA & ROI & NPM & ROE \\
\hline \multicolumn{6}{|l|}{$\mathrm{Ll}$. } \\
\hline LDL & -0.021456 & 0.0006049 & -0.0260315 & -0.0727343 & 0.2501824 \\
\hline SIZ & $0.1515141 * *$ & $0.0319302 * *$ & $0.0233237 *$ & $0.0778513 * *$ & -0.3909164 \\
\hline TANG & -0.2302618 & 0.0873658 & 0.0627171 & -0.1307578 & -0.4559223 \\
\hline GROW & 0.0006524 & $0.000966 * * *$ & $0.0008595 * *$ & 0.0008507 & 0.0071833 \\
\hline RISK & 0.3684463 & $-0.6628517 * * *$ & $-0.6735473 * * *$ & -0.3933116 & $-13.88023 * * *$ \\
\hline LIQ & 0.00301 & $0.0019933^{*}$ & $0.0019625 *$ & $0.0048047 * * *$ & -0.0013443 \\
\hline INFL & -0.0081474 & 0.0012524 & 0.0014369 & 0.0006418 & -0.008909 \\
\hline AGE & -0.0167977 & 0.0102848 & -0.0016351 & -0.0728407 & -0.2961424 \\
\hline Constant & $-3.248538 * *$ & $-0.7799971 * *$ & $-0.5395722 *$ & $-1.523662 *$ & $10.98438 *$ \\
\hline Observations & 171 & 171 & 171 & 171 & 171 \\
\hline $\mathrm{R}-\mathrm{sq}$ & 0.0312 & 0.3216 & 0.3041 & 0.2304 & 0.2 \\
\hline rho & 0.46589646 & 0.1003418 & 0.04478868 & 0.53962907 & 0 \\
\hline Hausman test-Prob $>$ chi 2 & 0.7349 & $0.000 * * *$ & $0.000 * * *$ & $0.0015 * * *$ & $0.0086 * * *$ \\
\hline Prob > F (Wald chi2) & 0.197 & $0.000 * * *$ & $0.000 * * *$ & $0.006 * * *$ & 0.0322 \\
\hline
\end{tabular}


Table A2.3. System-GMM results

\begin{tabular}{|c|c|c|c|c|c|}
\hline Factor & PROF & ROA & ROI & NPM & ROE \\
\hline Ll. & $0.0944692 * * *$ & 0.0519858 & -0.0281694 & $0.0665705 * * *$ & $-0.4892893 * * *$ \\
\hline LDL & -0.0593632 & -0.010107 & -0.0211001 & $-0.0717036 * *$ & $-0.4046728 * *$ \\
\hline SIZ & $0.1860851 * * *$ & $0.0385994 * * *$ & $0.0297349 * * *$ & $0.0957793 * *$ & $0.2317589 * * *$ \\
\hline TANG & $-0.5079063 * *$ & 0.0413407 & 0.0337424 & $-0.1980273^{*}$ & $-1.133802 * *$ \\
\hline GROW & 0.0003562 & $0.0006048 *$ & $0.0005673 * *$ & -0.0000825 & $-0.0091621 * * *$ \\
\hline RISK & $1.097404 * *$ & $-0.3628025 * *$ & $-0.5547813 * * *$ & 0.2831942 & $11.92324 * * *$ \\
\hline LIQ & 0.0016537 & $0.00201 * *$ & $0.0020763 * *$ & $0.0049976 * * *$ & $-0.0133543 * *$ \\
\hline INFL & -0.0088436 & 0.0016143 & 0.0018323 & -0.0010894 & 0.0198914 \\
\hline $\mathrm{AGE}$ & -0.0576632 & -0.0018871 & -0.0120059 & -0.0742328 & $-0.6357503 * * *$ \\
\hline Constant & $-3.763307 * * *$ & $-0.8848833 * * *$ & $-0.6436034 * * *$ & $-1.862258 * * *$ & $-3.052275^{*}$ \\
\hline Observations & 162 & 162 & 162 & 162 & 162 \\
\hline Prob > F (Wald chi2) & $0.000 * * *$ & $0.000 * * *$ & $0.000 * * *$ & $0.000 * * *$ & $0.000 * * *$ \\
\hline $\operatorname{AR}(1) \operatorname{Pr}>z$ & $0.004 * * *$ & $0.000 * * *$ & $0.000 * * *$ & $0.047 * *$ & $0.017 * *$ \\
\hline $\mathrm{AR}(2) \operatorname{Pr}>\mathrm{z}$ & 0.812 & 0.864 & 0.975 & 0.620 & 0.575 \\
\hline Sargan test-Prob $>$ chi2 & 0.009 & $0.000 * * *$ & $0.000 * * *$ & $0.000 * * *$ & $0.000 * * *$ \\
\hline
\end{tabular}

Relationship between short-term debt leverage (SDL) and financial performance regression results

Table A3.1 Fixed effects (FE) results

\begin{tabular}{lccc}
\hline \multicolumn{1}{c}{ Factor } & PROF & ROA & ROI \\
\hline Ll. & & & ROE \\
SDL & $-0.5684958 * *$ & $-0.6112865 * * *$ & $-0.6189712 * * *$ \\
SIZ & 0.0719496 & $0.1053069 * *$ & $0.1287635 * * *$ \\
TANG & -0.3922782 & 0.0241405 & -0.0226104 \\
GROW & 0.0005717 & $0.0009497 * * *$ & $0.0009209 * * *$ \\
RISK & 0.3648462 & $-0.3293116 *$ & $-0.3083694 *$ \\
LIQ & 0.0003104 & -0.0000836 & -0.0002626 \\
INFL & $-0.009734 *$ & 0.0005462 & 0.0008016 \\
AGE & -0.2052197 & -0.0245797 & -0.1102591 \\
Constant & -0.5312938 & $-2.091752 *$ & $-2.333743 * * *$ \\
obsevations & 171 & 171 & $0.0225003 *$ \\
R-sq & 0.0879 & 0.6754 & 0.0177215 \\
rho & 0.5223966 & 0.85321058 & 0.0156576 \\
Hausman test-Prob $>$ chi2 & 0.8672 & $0.000 * * *$ & 0.6748 \\
Prob $>$ F (Wald chi2) & 0.134 & $0.000 * * *$ & 0.87884888 \\
\end{tabular}

Table A3.2 Random effects (RE) results

\begin{tabular}{lcccc}
\hline \multicolumn{1}{c}{ Factor } & PROF & ROA & ROI & ROE \\
\hline Ll. & & & & \\
SDL & $-0.5310339^{* * *}$ & $-0.3813201^{* * *}$ & $-0.359416^{* * *}$ & 0.5187438 \\
SIZ & $0.1309253^{* *}$ & 0.013612 & 0.0054575 & -0.3623065 \\
TANG & $-0.5625301^{*}$ & -0.0299259 & -0.0520198 & -0.1916729 \\
GROW & 0.0001723 & $0.0011322^{* * *}$ & $0.0011124^{* * *}$ & 0.007012 \\
RISK & 0.8435435 & $-0.5098246^{* * *}$ & $-0.5482832^{* * *}$ & $-14.08736^{* * *}$ \\
LIQ & 0.0007253 & 0.0002902 & 0.0002825 & 0.0014467 \\
INFL & $-0.0090631^{*}$ & 0.0007136 & 0.0010699 & -0.0092609 \\
AGE & -0.036584 & 0.0106978 & -0.0058711 & -0.2525757 \\
Constant & $-2.378489^{*}$ & -0.1858808 & 0.0390187 & 9.991629 \\
Observations & 171 & 171 & 171 & 171 \\
R-sq & 0.0791 & 0.6465 & 0.6331 & 0.2092 \\
rho & 0.45356424 & 0.28531912 & 0.19716271 & 0 \\
Hausman test-Prob>chi2 & 0.8672 & $0.000^{* * *}$ & $0.000^{* * *}$ & $0.0027 * * *$ \\
Prob $>$ F (Wald chi2) & $0.0045^{* * *}$ & $0.000^{* * *}$ & $0.000^{* * *}$ & $0.0306^{* * *}$ \\
\hline
\end{tabular}


Table A3.3. System-GMM results

\begin{tabular}{|c|c|c|c|c|}
\hline Factor & PROF & ROA & ROI & ROE \\
\hline Ll. & $0.0856073 * * *$ & -0.0202352 & $-0.1391868 * *$ & $-0.4884315 * * *$ \\
\hline SDL & $-0.4520346 * * *$ & $-0.2618692 * * *$ & $-0.2804951 * * *$ & $0.580584 * *$ \\
\hline $\mathrm{SIZ}$ & $0.1589149 * * *$ & $0.0227317 * * *$ & 0.011921 & $0.2689615 * * *$ \\
\hline TANG & $-0.6327641 * * *$ & -0.0434846 & -0.0732945 & $-1.120133 * *$ \\
\hline GROW & 0.0003828 & $0.0005563 * *$ & $0.0004776 * *$ & $-0.0091261 * * *$ \\
\hline RISK & $1.379012 * * *$ & $-0.3099379 * *$ & $-0.5725694 * * *$ & $11.39159 * * *$ \\
\hline LIQ & -0.0011473 & 0.0004768 & 0.0005148 & -0.0091655 \\
\hline INFL & -0.0093225 & 0.0013978 & 0.0017344 & 0.0213571 \\
\hline AGE & -0.0603815 & -0.009458 & $-0.0260574 *$ & $-0.6611717 * * *$ \\
\hline Constant & $-2.921289 * * *$ & $-0.3667158 * *$ & -0.0506086 & $-4.129137 * *$ \\
\hline Observations & 162 & 162 & 162 & 162 \\
\hline Prob > F (Wald chi2) & $0.000 * * *$ & $0.000 * * *$ & $0.000 * * *$ & $0.000 * * *$ \\
\hline $\operatorname{AR}(1) \operatorname{Pr}>z$ & $0.004 * * *$ & $0.000 * * *$ & 0.705 & $0.01 * * *$ \\
\hline $\operatorname{AR}(2) \operatorname{Pr}>z$ & 0.769 & 0.333 & 0.675 & 0.689 \\
\hline Sargan test-Prob > chi2 & $0.02 * *$ & $0.000 * * *$ & $0.000 * * *$ & $0.000 * * *$ \\
\hline
\end{tabular}

